\title{
Research on the tax support policy for implementing the Extended Producer Responsibility - Taking End-of-Life Vehicle Collecting and Dismantling Enterprises as an Example
}

\author{
Lulu Huo ${ }^{1, *}$, Jia Wang ${ }^{1}$, Yonghe Huang ${ }^{1}$, Yuke $\mathrm{Li}^{1}$, Wei $\mathrm{Pan}^{1}$, Zhenbiao $\mathrm{Li}^{1}$ and Hong Shi ${ }^{1}$ \\ ${ }^{1}$ China Automotive Technology \& Research Center Co., Ltd., China
}

\begin{abstract}
The Extended Producer Responsibility (EPR) is an important system for improving resource reuse rate and reducing waste pollution to the environment. Aiming at automobile products, this article takes endof-life vehicles collecting and dismantling enterprises as an example. By studying the support from tax support policy, tax incentives are provided to those enterprises that meet safety and environmental protection requirements. In this way, it can guide enterprises to improve safety and environmental protection and reduce corporate pressure from taxation. This article also predicts the effect of energy conservation and environmental protection after the implementation of tax support policy and demonstrates the importance of tax support policy of implementing the EPR.
\end{abstract}

\section{Instruction}

China has successively promulgated the Law of the People's Republic of China on Prevention and Control of Environmental Pollution by Solid Waste, Law of the People's Republic of China on Promoting Clean Production, Law of the People's Republic of China on Promoting Circular Economy and other laws to reduce pollution from the source, improve resource utilization efficiency and put forward corresponding requirements in terms of producer responsibility. China has successively introduced a series of related policies, regulations and standards. However, when it comes to automotive products, China currently does not have a strong upperlevel legal basis, specific and unified supporting management policies. Even if there are requirements, no supervision and monitoring are conducted on the implementation of the EPR for auto manufacturers.

During the implementation of the EPR, a key link is the collection of end-of-life vehicles (ELVs) . However, the current ELVs collecting and dismantling enterprises can not obtain special input tax invoices for deductions during the car scrapping and recycling process, which greatly increases the operating costs of enterprises, significantly reduces profit margin and is not conducive to enhancing the competitiveness of formal enterprises and guiding the orderly collecting and recycling of ELVs.

Difficulty in the operation of the disassembled link has created obstacles for the producers to fulfill the EPR. In order to promote the full implementation of EPR in the automobile industry in China, China is considering implementing preferential tax policies in the ELVs collecting and dismantling enterprises, so as to effectively reduce the tax costs borne by enterprises, increase profitability and improve China's level in recycling and dismantling of ELVs.

\section{Ideas of tax support policies}

\subsection{Principles}

Principle of legality: The formulation and implementation of preferential tax policies must be legal and should ensure system design and implementation procedures are standard.

Principle of coordination: The policy aims at promoting the implementation of the EPR, but the policy should be designed by coordinating the interests of various subjects, improving ecological efficiency, taking into account fairness and efficiency, and ensuring the overall stability of fiscal revenue.

Principle of flexibility: The policy design and settings should meet the requirements for dynamic adjustment and can be adjusted in time by considering the implement of policies and changes in the external environment of implementing policies.

Principle of convenience: The policy should be designed by fully considering the operability and putting forward relevant suggestions based on the existing policy system as much as possible to ensure the effect of operating the tax preference system.

\subsection{Design of tax system}

At present, the main taxes involved in the business related to the ELVs collecting and dismantling business are valueadded tax (VAT) and enterprise income tax. Whether VAT

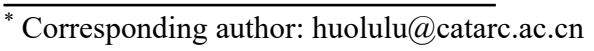


can be deducted from the input tax directly affects the cash flow of enterprises and is related to the collection price of ELVs. In addition, VAT, as the tax base of additional tax, plays an important role in operating profits together with enterprise income tax. The design of preferential tax policies should focus on the tax collection mechanism and tax rate setting of VAT and enterprise income tax.

- In view of the difficulty in obtaining VAT input invoices for enterprises in the process of collecting and deducting the limited input tax, it is recommended to implement simple tax collection methods for the sales of scrapped steel and second-hand parts by enterprises. Enterprises can choose to calculate and pay VAT at the tax rate of $3 \%$ by using the simplified method.

- In order to support the development of key enterprises, it is recommended to levy enterprise income tax at the tax rate of $15 \%$ by comparing the preferential enterprise income tax policies for high-tech enterprises to those with high investment in environmental protection and meet the relevant review requirements in order to support the development of key enterprises in view of the advanced technology of recycling and dismantling of scrapped vehicles, high equipment purchase investment and long investment return period.

- In order to further enhance the enthusiasm of enterprises, promote scrapped automobile recycling and dismantling enterprises to improve the level of environmental protection, increase automobile collecting prices, reduce the flow of ELVs into an illegal market and improve the overall recycling rate of automobiles, it is recommended to deduct taxable income at the rate of $50 \%$ of the actual amount by referring to the extra tax deduction policy for R\&D expenses.

Table 1. Tax support policy for implementing the EPR

\begin{tabular}{|c|c|c|}
\hline Tax Type & Current Policy & $\begin{array}{c}\text { Recommendations } \\
\text { for Policy }\end{array}$ \\
\hline $\begin{array}{c}\text { Value- } \\
\text { added tax }\end{array}$ & $\begin{array}{c}\text { General tax } \\
\text { calculation method, } \\
\text { at the tax rate of } 13 \%\end{array}$ & $\begin{array}{c}\text { Simple tax } \\
\text { calculation method, } \\
\text { at the tax rate of } 3 \%\end{array}$ \\
\hline $\begin{array}{c}\text { Enterprise } \\
\text { income tax }\end{array}$ & $\begin{array}{c}\text { Tax rate: } 15 \% \text { for } \\
\text { high-tech enterprises, } \\
25 \% \text { for others }\end{array}$ & $\begin{array}{c}\text { Meet EPR-related } \\
\text { evaluation } \\
\text { requirements, at the } \\
\text { tax rate of } 15 \%\end{array}$ \\
\hline & $\begin{array}{c}\text { Extra tax deductions } \\
\text { for R\&D expenses: } \\
50 \%\end{array}$ & $\begin{array}{c}\text { Extra tax deductions } \\
\text { for EPR-related } \\
\text { investment, at the tax } \\
\text { rate of } 50 \%\end{array}$ \\
\hline
\end{tabular}

\subsection{Safeguard measures}

The establishment of an EPR evaluation system can ensure the smooth implementation of preferential tax policies. At present, the automotive industry is studying the establishment of a responsibility extension evaluation system for automotive manufacturers. Based on the evaluation system, the evaluation criteria can be organically combined with the applicable conditions of tax preferential policies. Relying on clear assessment indicators and scoring standards, quantifiable evaluation results can be used as the basis for determining whether tax preferential policies are granted, increasing the operability of policies, ensuring simple policy implementation and controlling the whole process.

\section{Evaluation on policy effect}

\subsection{Calculation and estimate of business scale and tax reduction}

\subsubsection{Effect of tax reduction on the recycling of scrapped automobiles}

The adjustment of VAT calculation method is conducive to saving the tax cost born by enterprises. The preference to enterprise income tax is conducive to improving the profitability of enterprises and increasing the overall collecting price level of the industry, thereby expanding the total collecting of ELVs.

- The statistics from the China National Resources Recycling Association show that the total VAT levied in the ELVs collecting and dismantling enterprises across the country in 2019 was about RMB2 billion. Based on this calculation, if the preferential VAT policy is implemented, the industry can save about RMB1.5 billion in tax costs, the operating profit generated in the industry is RMB3.16 billion and the preferential tax rate can increase the profit by about RMB300 million.

- Assuming that enterprises may provide $50 \%$ of the cost savings and increased profits for increasing the automobile collecting price, the average collecting price of a single car can increase by RMB400 or so.

- Referring to the elasticity coefficient of demand for automobile prices (1\% reduction in the purchase cost can drive sales growth by approximately $2.6 \%$ ), the average collecting price of a single car increases by RMB400, accounting for approximately $0.4 \%$ of the car purchase cost. It is expected to drive the sales of old-for-new cars (namely the total amount of scrapped cars) to increase by $1.0 \%$ of the car sales in the year, i.e. 250,000 cars.

\subsubsection{Role of additional tax deduction policy in stimulating the investment in the EPR}

Based on the estimation of industry research, the current investment in safety and environmental protection of ELVs collecting and dismantling enterprises is about $10 \%$ of annual sales. Based on industry sales data in 2019, it was about RMB3 billion. If the additional tax deduction policy is implemented, the taxable income may be reduced by RMB 1.5 billion and the income tax may be reduced by RMB380 million.

In addition, as the policies for promoting the implementation of the EPR system in next step, production enterprises will increase investment in this area in the future. The additional tax deduction policy will help reduce the dependence of industry development on financial subsidies and form a virtuous rolling development mechanism. 


\subsubsection{Role of additional tax deduction policy in stimulating the investment in the EPR}

Adjustment in VAT calculation method: According to the statistical tax data from China National Resources Recycling Association, the total VAT generated by the industry in 2019 was about RMB2 billion. Considering the fact that some enterprises are engaged in serious tax evasion by using the formal tax calculation method, the tax calculation method is adjusted by referring to the data about estimate of industry operating income in 2019, which will increase the enthusiasm of enterprises to pay taxes payable. VAT can be estimated based on sales. After the implementation of the policy, the scale of the industry will increase by about $11 \%$, with sales about RMB33 billion and VAT about RMB1 billion. Therefore, VAT has actually been reduced by RMB1 billion after the implementation of the policy.

Preferential enterprise income tax rate: According to the data about calculation of industry operating profit, the total preferential tax rate reaches to RMB300 million .

Extra tax deduction policy: Based on the current industry input data, enterprise income tax has been reduced by RMB380 million after the implementation of the policy.

In summary, relying on comprehensive effect of various tax policies, the total reduction in VAT is RMB1 billion, the total reduction in enterprise income tax is
RMB380 million and the total tax reduction is RMB1.38 billion.

\subsection{Energy saving and environmental protection effect}

It is predicted that about additional 250,000 ELVs will be recycled through tax reduction. Calculated at $2.8 \mathrm{~T}$ per vehicle, new scrapped steel item is added and its theoretical value will exceed 500,000T. The composition ratio of ELVs materials and the estimation of the theoretical value of ELVs materials recycled are showed in Figure 1 and Table 2.

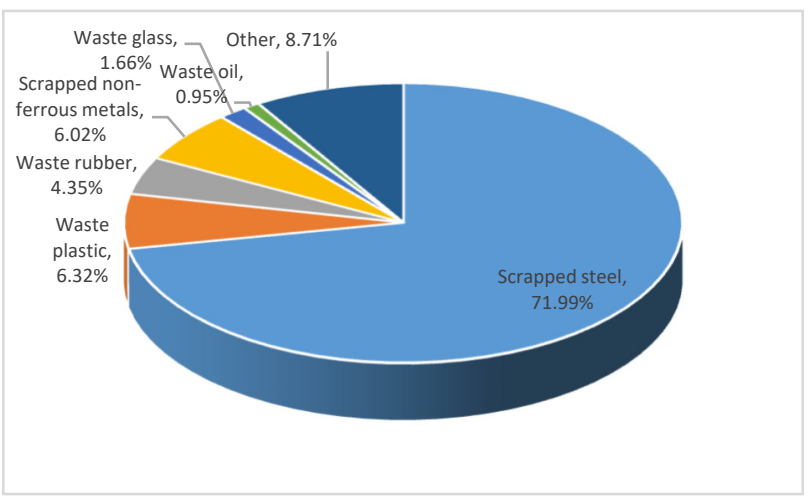

Fig. 1. Composition ratio of scrapped automobile materials.

Table 2. Estimation of the theoretical value of scrapped automobile materials recycled

\begin{tabular}{|c|c|c|c|c|c|c|c|}
\hline & $\begin{array}{c}\text { Scrapped } \\
\text { steel }\end{array}$ & $\begin{array}{c}\text { Waste } \\
\text { plastic }\end{array}$ & $\begin{array}{c}\text { Waste } \\
\text { rubber }\end{array}$ & $\begin{array}{c}\text { Waste } \\
\text { glass }\end{array}$ & $\begin{array}{c}\text { Scrapped } \\
\text { non-ferrous } \\
\text { metals }\end{array}$ & Waste oil & Other \\
\hline Weight of a single car (T) & 2.01572 & 0.17696 & 0.1218 & 0.04648 & 0.16856 & 0.0266 & 0.24388 \\
\hline Total (10,000T) & 50.393 & 4.424 & 3.045 & 1.162 & 4.214 & 0.665 & 6.097 \\
\hline
\end{tabular}

Some parts of the ELVs can be remanufactured. Remanufacturing is the highest form of resource reuse, which can save a lot of materials and reduce waste gas and solid waste generated. Taking a single engine as an example, each engine produced can save $59 \mathrm{~kg}$ steel, $8 \mathrm{~kg}$ aluminum and $170 \mathrm{~kW} \cdot \mathrm{h}$ electricity and reduce by $56 \mathrm{~kg}$ carbon dioxide, $6 \mathrm{~kg}$ carbon monoxide, $1 \mathrm{~kg}$ nitrogen oxides, $4 \mathrm{~kg}$ sulfides and $290 \mathrm{~kg}$ solid waste. It is estimated that $5 \%$ of the engines in ELVs are remanufactured. Relying on policy support, 12,500 remanufactured engines are added, 8,375,000T steel and aluminum are saved, $2,125,000 \mathrm{~kW} \cdot \mathrm{h}$ electricity is saved, $837.5 \mathrm{~T}$ carbon dioxide and 36,250,000T solid waste are reduced.

Table 3. Estimation of energy saving and emission reduction of remanufactured products

\begin{tabular}{|c|c|c|c|r|r|r|r|r|}
\hline & $\begin{array}{c}\text { Steel } \\
(\mathbf{T})\end{array}$ & $\begin{array}{c}\text { Aluminu } \\
\text { m (T) }\end{array}$ & $\begin{array}{c}\text { Power saved } \\
(\mathbf{1 0 , 0 0 0} \text { kW॰h) }\end{array}$ & $\begin{array}{c}\text { Carbon } \\
\text { dioxide (T) }\end{array}$ & $\begin{array}{c}\text { Carbon } \\
\text { monoxide (T) }\end{array}$ & $\begin{array}{c}\text { Nitrogen } \\
\text { oxide (T) }\end{array}$ & $\begin{array}{c}\text { Sulfide } \\
\text { (T) }\end{array}$ & $\begin{array}{c}\text { Solid } \\
\text { waste (T) }\end{array}$ \\
\hline $\begin{array}{c}\text { Overall } \\
\text { index }\end{array}$ & 737.5 & 100 & 212.5 & 700 & 75 & 12.5 & 50 & 3625 \\
\hline
\end{tabular}

\section{Conclusion}

\subsection{Tax support can effectively guide manufacturers to implement the EPR}

Tax support policies can effectively eliminate the financial obstacles that restrict manufacturers from implementing the EPR. Firstly, these policies can reduce corporate tax costs, increase corporate profitability, expand the industry scale and smooth the industrial chain of ELVs collecting and dismantling. Secondly, these policies can increase the enthusiasm of manufacturers in investment. Automobile manufacturers generally have larger production scales. The improvement in the enthusiasm of manufacturer to implement the EPR is conducive to accelerating the industry technology and equipment upgrades and forming large-scale development. Thirdly, some materials are processed with low economic value but high 
environmental protection value in the current automobile collecting and recycling process, while some large-scale equipment requires large capital investment. The preferential income tax policy can change the ideas about the development of the industry. More taxation polices can be used to support the development instead of the direct financial subsidies, which is more conducive to promoting healthy competition in the industry.

\subsection{The implementation of the EPR plays an important role in promoting resource conservation}

The main purpose of the EPR system is to improve resource reuse rate and reduce waste pollution to the environment. It emphasizes not only producer responsibility, but also the sharing of responsibilities among different roles in the entire product life chain. The EPR considers the different roles involved in the product life chain, including consumers, sellers, recyclers, waste processors, central and local governments. In this research, based on the analysis of ELVs collecting and dismantling enterprises, it can be seen that the EPR has played a very important role in promoting resource conservation and the EPR has created significant effects on saving steel, aluminum and electricity and reducing carbon dioxide and solid waste generated.

\section{Acknowledgement}

This work was supported by Joint research on advanced technologies of electric vehicles for Sino-US cooperation (2019YFE0100200).

\section{References}

1. JL.Sun, Nj.Zheng. Research on Recycling Technology Applicable for Scrapped Automobile Materials[J]. Materials Review. 2012, 26(S2), 127130

2. M.Chen. Research on Key Technologies Applicable for Material Efficiency-oriented Recycling of Automobile Products[J]. China Mechanical Engineering. 2018, 29(21), 2615-2625

3. L.Liu, H.Li. Several Principles to be Followed in Formulating Tax Incentives [N] 2015-03-25 (B02) S. Wang, G. Fan, J. Yu. The Trace and Features of EPR in ELV Recycling System: Comparison of International Trend[C]. Proceedings of the 28th Annual Conference of Japan Society of Material Cycles and Waste Management, 2017 